\title{
OPTIMALISASI PENERIMAAN PENDAPATAN ASLI DAERAH KOTA TIDORE KEPULAUAN
}

\author{
Muhammad Hi. Hasan \\ Staf Pengajar Fekon Univ. Nuku-Tidore, e-mail: -
}

\begin{abstract}
ABSTRAK
Mencermati situasi problematis yang dihadapi oleh Pemerintah Kota Tidore Kepulauan dalam menghadapi otonomi daerah karena kecilnya kemampuan keuangan daerah serta ketergantungan pada bantuan pusat yang sangat besar. Penelitian ini bertujuan untuk mengetahui dan menganalisis kondisi keuangan daerah Kota Tidore Kepulauan ditinjau dari komponen Pendapatan Asli Daerah (PAD) yakni penerimaan pajak daerah, retribusi daerah, dan lain-lain pendapatan daerah yang sah serta mengetahui kebijakan Pemerintah Kota Tidore Kepulauan dalam rangka mengoptimalkan PAD di Kota Tidore Kepulauan. Berdasarkan hasil penelitian maka dapat disimpulkan bahwa kondisi keuangan daerah Kota Tidore Kepulauan ditinjau dari komponen PAD yakni penerimaan pajak daerah, retribusi daerah, dan lain-lain pendapatan daerah yang sah sudah cukup baik. Secara umum, pertumbuhan PAD Kota Tidore Kepulauan selama periode 2006-2010, terlihat bahwa selama dua tahun terakhir kinerja pemerintah daerah dalam menggenjot PAD belum optimal. Dengan berlakunya UndangUndang Nomor 22 Tahun 1999 dan Undang-Undang Nomor 25 Tahun 1999, maka berbagai kewenangan telah dimiliki oleh Pemerintah Daerah pada umumnya dan Pemerintah Kota Tidore Kepulauan pada khususnya, namun dalam pelaksanaannya masih banyak kewenangan yang belum dilaksanakan secara optimal, baik secara intensifikasi maupun secara ekstensifikasi.
\end{abstract}

Kata Kunci: Tidore kepulauan, pendapatan

\section{PENDAHULUAN}

\subsection{Latar Belakang Masalah}

Sejak diberlakukannya otonomi daerah pada tanggal 1 Januari 2001 lalu, telah terjadi pelimpahan kewenangan yang semakin luas kepada pemerintahan daerah dalam rangka meningkatkan efektifitas dan efisiensi penyelenggaraan fungsi pemerintah daerah. Desentralisasi kewenangan dalam implementasi otonomi daerah sangat diperlukan dengan pertimbangan bahwa : (1). Semakin mendekati kebutuhan masyarakat lokal, maka semakin efektif fungsi organisasi pemerintahan, (2). Daerah akan mengalami proses pemberdayaan yang signifikan, karena kemampuan prakarsa dan kreativitas mereka akan terpacu, sehingga kapabilitasnya dalam mengatasi berbagai masalah domestik akan semakin kuat, dan (3). Karena semakin beragam kebutuhan masyarakat dewasa ini, serta akibat terbatasnya kemampuan pemerintah pusat dalam menangani berbagai persoalan dan tuntutan masyarakat, maka kebutuhan akan desentralisasi yang luas dan nyata semakin diperlukan (Rasyid, dkk 2002).

Dari segi ekonomi, desentralisasi kewenangan di bidang pemerintahan memberikan tekanan yang kuat pada aspek keuangan daerah dalam berbagai aktivitas rutin pemerintahan dan pembangunan dalam rangka pemberian pelayanan kepada masyarakat yang menjadi tanggung jawabnya. Karena terbatasnya kemampuan keuangan daerah, maka terasa sangat sulit bagi pemerintah daerah untuk mengimplementasikan semua kewenangan di bidang pemerintahan yang dilimpahkan pusat kepadanya. Atas dasar pertimbangan yang demikian itu, maka pemerintah pusat menyerahkan sebagian kewenangan di bidang keuangan kepada pemerintah daerah dalam bentuk pelaksanaan kebijakan desentralisasi fiskal.

Implementasi otonomi daerah dan juga pemerintahan dan pembangunan daerah bisa diwujudkan hanya apabila disertai otonomi 


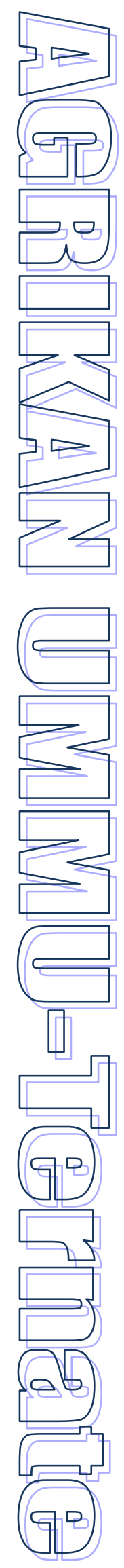

keuangan yang efektif. Ini berarti bahwa, pemerintah daerah secara finansial harus bersifat independen terhadap pemerintah pusat dengan jalan menggali sebanyak mungkin sumbersumber pendapatan asli daerah (PAD) seperti pajak daerah, retribusi retribusi, dan sebagainya. Independensi pemerintah daerah secara finansial, akan membentuk derajat otonomi fiskal daerah ke arah yang lebih tinggi. Pemberian otonomi daerah ini diharapkan dapat meningkatkan efisiensi, efektivitas, dan akuntabilitas sektor publik di Indonesia. Dengan otonomi, daerah dituntut untuk mencari alternatif sumber pembiayaan pembangunan tanpa mengurangi harapan masih adanya bantuan dan bagian (sharing) dari pemerintah pusat dan menggunakan dana publik sesuai dengan prioritas dan aspirasi masyarakat (Mardiasmo, 2002).

Otonomi daerah tersebut juga termasuk didalamnya desentralisasi fiskal yang mengharuskan daerah mempunyai kemandirian keuangan yang tinggi. Desentralisasi fiskal dilakukan pada saat daerah mempunyai tingkat kemampuan yang berbeda-beda (Adi, 2006). Beberapa daerah dengan sumber daya yang dimiliki mampu menyelenggarakan otonomi daerah, namun tidak tertutup kemungkinan ada beberapa daerah akan menghadapi kesulitan dalam menyelenggarakan tugas desentralisasi, mengingat keterbatasan sumber daya yang dimiliki (Bappenas, 2003).

Menurut Rasyid (2000:88) ciri utama yang menunjukkan suatu daerah otonom mampu menyelenggarakan otonomi daerahnya, terletak pada kemampuan keuangan daerah. Senada dengan hal tersebut, Halim (2004:22) dan Sidik (2002:8) menyebutkan bahwa ciri utama yang menunjukkan suatu daerah otonom mampu berotonomi yaitu terletak pada kemampuan keuangan daerah. Artinya, daerah otonom harus memiliki kewenangan dan kemampuan untuk menggali sumber-sumber keuangan sendiri, mengelola dan menggunakan keuangan sendiri yang cukup untuk membiayai penyelenggaraan pemerintahan daerahnya. Ketergantungan kepada bantuan pusat harus seminimal mungkin, dan diharapkan bahwa Pendapatan Asli Daerah (PAD) harus menjadi bagian terbesar dalam memobilisasi dan menyelenggarakan pemerintahan daerah.

Dalam pelaksanaan otonomi daerah, pemerintah daerah memegang peran yang sangat vital dalam merencanakan pembangunan, mengalokasikan dan pengelolaan sumber-sumber yang ada di daerah untuk pelayanan kepada masyarakat dengan tujuan akhir adalah kesejahteraan masyarakat itu sendiri. Kota Tidore Kepulauan sebagai salah satu daerah kabupaten kota di Indonesia memiliki kewajiban dan tantangan yang sama dengan daerah lainnya. Bagi Pemerintah Daerah dalam menjalankan otonominya haruslah didukung oleh adanya sumber-sumber keuangan yang memadai untuk membiayai otonominya. Kurangnya sumber keuangan akan menyebabkan Pemerintah Daerah mengurangi standar pelayanan yang diberikan dan apabila dibiarkan akan menciptakan externalities yang akan merugikan kepentingan nasional

Untuk dapat mengoptimalkan pelaksanaan otonomi daerah, baik yang menyangkut dengan praktek penyelenggaraan kegiatan rutin pemerintahan maupun pelaksanaan berbagai kegiatan pembangunan, maka setiap daerah di Indonesia harus memiliki sumber-sumber pendapatan yang potensial. Hal ini dimaksudkan agar daerah memiliki kemampuan yang besar untuk membiayai kegiatan-kegiatan rutin pemerintahan dan pembangunan yang dilaksanakannya dan secara bertahap dapat mengurangi ketergantungannya terhadap keuangan pemerintah pusat. Akan tetapi, kondisi obyektif anggaran pendapatan daerah dalam APBD Kota Tidore Kepulauan periode 20062010 memperlihatkan bahwa, pendapatan daerah di kota ini masih mengandalkan penerimaan dari sumber dana perimbangan. Secara kumulatif dalam periode tersebut, pendapatan asli daerah (PAD) baru memberikan kontribusi rata-rata sebesar Rp 5,700,533,805 atau 2,46\% per tahun anggaran terhadap pendapatan daerah total.

Kondisi anggaran pendapatan daerah Kota Tidore Kepulauan pada tahun 2010 belum mengalami perubahan yang berarti dan komposisinya masih didominasi oleh pendapatan yang bersumber dari dana perimbangan dengan kecenderungan yang meningkat. Pada tahun anggaran tersebut, dari total pendapatan daerah sebesar Rp 176.620.037,- atau 50,09\%, dana perimbangan memberikan kontribusi Rp 1.238.140.855,- atau $81,31 \%$, sedangkan selebihnya dikontribusikan masing-masing oleh komponen Pendapatan Asli Daerah (PAD) sebesar Rp 6.450.318.716,- dan lain pendapatan daerah yang sah $\mathrm{Rp} 1.026 .062 .634$,- atau sebesar $.12 \%$. Terlihat dari struktur pendapatan daerah di Kota Tidore Kepulauan yang terbentuk rata-rata ,8 \% bersumber dari dana perimbangan terhadap total pendapatan daerah, itu berarti derajat desentralisasi dan otonomi fiskal daerah 
di kota ini masih relatif rendah. Dengan perkataan lain, dalam periode 2006-2010 kebutuhan dana untuk pembiayaan berbagai aktivitas rutin pemerintahan dan pembangunan daerah masih memiliki ketergantungan yang tinggi terhadap keuangan pemerintah pusat.

Tabel 1. Realisasi Pendapatan Daerah di Kota Tidore Kepulauan Tahun 2006-2010

\begin{tabular}{|c|c|c|c|c|c|c|}
\hline \multirow[b]{2}{*}{ Tahun } & \multicolumn{4}{|c|}{ Pendapatan Daerah (Rp.) } & \multirow{2}{*}{$\begin{array}{l}\text { Pendapatan } \\
\text { Daerah Total } \\
\text { (Rp 000) }\end{array}$} & \multirow[b]{2}{*}{$\%$} \\
\hline & PAD & $\begin{array}{c}\% \\
\text { Perubahan }\end{array}$ & $\begin{array}{c}\text { Dana } \\
\text { Perimbangan }\end{array}$ & $\begin{array}{l}\text { Lain-lain Pendapatan } \\
\text { Daerah yang Sah }\end{array}$ & & \\
\hline 2006 & 5.237 .525 .048 & 139 & 19.696.940.232, & 2.421.418.502 & 32.556 .600 & 14 \\
\hline 2007 & 7.740 .147 .441 & 187 & 4.746.147.330,-- & 3.064 .416 .863 & 56.808 .650 & 161 \\
\hline 2008 & 7.329.361.321 & 128 & & 2.668 .149 .766 & 489.587 .825 & 490 \\
\hline 2009 & 7.242.978.525 & 86 & $\begin{array}{r}\text { 261.13.970.000, } \\
30.544 .275 .000,-\end{array}$ & 1.627.985.851 & 1.076.200.37 & 201 \\
\hline 2010 & 6.450 .318 .716 & 76 & 2.209.814.961,-- & 1.206 .062 .634 & 344.111 .759 & 89 \\
\hline Rata-rata & 37.222 .319 .007 & 6.16 & 1.238.140.855,- & 64.306 .558 .715 & 176.620 .037 & 50.09 \\
\hline
\end{tabular}

Berbagai kebijakan telah dikembangkan oleh Pemerintah Daerah Kota Tidore Kepulauan dalam mengatasi masalah derajat desentralisasi dan otonomi fiskal daerah. Akan tetapi, alokasi dana perimbangan dari pemerintah pusat terutama yang bersumber dari DAU dalam setiap tahun yang lebih besar dari proporsi kemampuan pemerintah daerah dalam merealisasikan PAD dan BHPBP mengakibatkan derajat desentralisasi dan otonomi fiskal daerah di kota ini menjadi rendah.

Berdasarkan uraian tersebut penulis ingin mengkaji sejauhmana konstribusi dan pengaruh sumber-sumber pendapatan asli daerah yang terdiri dari realisasi penerimaan pajak daerah, retribusi daerah, dan lain-lain pendapatan daerah yang sah terhadap total penerimaan daerah.

\subsection{Tujuan dan Manfaat Penelitian}

Tujuan yang ingin dicapai dalam penelitian ini adalah:

1. Untuk mengetahui dan menganalisis kondisi keuangan daerah Kota Tidore Kepulauan ditinjau dari komponen Pendapatan Asli Daerah (PAD) yakni penerimaan pajak daerah, retribusi daerah, dan lain-lain pendapatan daerah yang sah.

2. Mengetahui kebijakan Pemerintah Kota Tidore Kepulauan dalam rangka mengoptimalkan PAD di Kota Tidore Kepulauan.

Adapun manfaat dan kegunaan yang diharapan dari penelitian ini adalah:

1. Untuk menambah pengetahuan dan wawasan peneliti tentang keuangan daerah khususnya berkaitan dengan optimalisasi sumber-sumber penerimaan Pendapatan Asli Daerah.

2. Diharapkan dapat memberikan kontribusi dan sumber pemikiran yang baru berdasarkan pendekatan empiris guna menambah khasanah pengetahuan khususnya menyangkut kajian kebijakan manajemen keuangan daerah.

3. Diharapkan dapat memberikan masukan atau informasi bagi Pemerintah Daerah Kota Tidore Kepulauan sebagai acuan dalam pengambilan keputusan atau kebijakan pada masa yang akan datang ditujukan untuk peningkatan peranan PAD dalam rangka pelaksanaan otonomi daerah.

4. Diharapkan dapat menjadi referensi tambahan bagi penelitian selanjutnya

\section{METODE PENELITIAN}

\subsection{Waktu Dan Lokasi Penelitian}

Penelitian ini dilakukan pada bulan Pebruari sampai bulan September tahun 2011 Daerah penelitian yang merupakan objek penelitian ini berlokasi di Kota Tidore Kepulauan (TIKEP)

\subsection{Jenis Penelitian}

Berdasarkan pada tujuan penelitian maka bentuk penelitian yang akan digunakan adalah penelitian desktriptif dengan tujuan mendeskripsikan secara sistimatis, factual, dan akurat terhadap suatu populasi atau daerah tertentu mengenai berbagai sifat dan factor tertentu. Penelitian deskriptif yang dimaksud dalam pelam penelitian ini adalah mencoba mendeskripsikan kondisi keuangan daerah Kota 


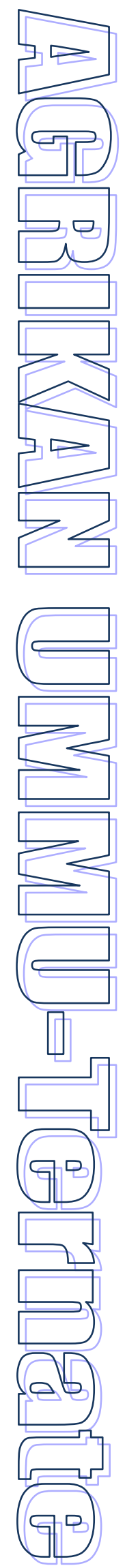

Tidore Kepulauan dan kebijakan Pemerintah Kota Tidore Kepulauan terkait dengan penerimaan Pajak daerah, Retribusi daerah dan Lain-lain pendapatan daerah yang sah sebagai kekuatan untuk menunjang optimalisasi penerimaan pendapatan asli daerah Kota Tidore Kepulauan

\subsection{Teknik Pengumpulan Data}

Kualitas data sangat menentukan kualitas penelitian. Kualitas data tergantung dari kualitas alat (instrument) yang digunakan untuk mengumpulkan data penelitian. Instrument dalam penelitian ini adalah peneliti dan juga dibantu dengan pedoman wawancara. Sementara tehnik pengumpulan data digunakan:

1. Studi Pustaka. Metode pustaka dilakukan untuk mengumpulkan data sekunder yang dilakukan dengan cara mengumpulkan data yang relevan dari buku, jurnal, artikel, peraturan yang terkait dengan penelitian.

2. Dokumentasi. Metode dokumentasi dilakukan untuk mengumpulkan data sekunder yang dilakukan dengan meminta dokumen-dokumen yang dimiliki oleh Pemerintah Kota Tidore Kepulauan terkait dengan objek penelitian.

Dokumen yang diperlukan dalam penelitian ini. adalah berupa realisasi pendapatan asli daerah, pajak daerah, retribusi daerah, dan lain-lain pendapatan daerah yang sah, data tersebut yang diperoleh dari Dinas Pendapatan Daerah Kota Tidore Kepulauan (DISPENDA).

\subsection{Defenisi Operasional Variabel}

Pendapatan Asli Daerah (PAD), ini merupakan bagian penting dari penerimaan daerah. Semakin tinggi sumber PAD semakin tinggi daerah dalam menyelenggarkan otonomi daerah. Pendapatan asli daerah adalah penerimaan yang diperoleh dari sumber-sumber dalam wilayahnya sendiri yang dipungut berdasarkan Peraturan Daerah serta peruturan perundang-undangan yang berlaku. Sumber pendapatan asli daerah adalah :

\subsubsection{Pajak daerah (PjD)}

Pajak daerah adalah jumlah realisasi penerimaan pajak daerah ,meliputi realisasi berbagai jenis pajak daerah yang ada di Kota Tidore Kepulauan. Pajak daerah yang dihimpun Pemerintah Kota Tidore Kepulauan berasal dari penerimaan Pajak Hotel, Pajak Restoran, Pajak Hiburan, Pajak Reklame, Pajak Penerangan Jalan Umum, Pajak Pengambilan Bahan Galian
Golongan C. Pajak daerah diukur dalam satuan rupiah $(\mathrm{Rp})$

\subsubsection{Retribusi Daerah (ReD)}

Retribusi daearah merupakan realisasi penerimaan dari retribisi yang dipungut dari masyarakat oleh pemerintah Kota Tidore kepulauan. Retribusi daerah yang dihimpun oleh Pemerintah Kota Tidore Kepulauan berasal dari penerimaan Retribusi Pelayanan Kesehatan, Retribusi Penggantian Biaya KTP/Kartu Keluarga, Retribusi Pelayanan Pasar, Retribusi Pengujian Kendaraan Bermotor, Retribusi Penggantian Biaya Cetak Akte, Retribusi Surat Ukur dan Pas Kecil Kendaraan di Atas Air, Retribusi Sertifikat Kesempurnaan, Retribusi Bus Sekolah, Retribusi Pemakaian Kekayaan Daerah, Retribusi Terminal, Retribusi Tempat Khusus Parkir, Retribusi Pelayanan Kepelabuhan, Retribusi Jasa Tambat/Labuh, Retribusi Jasa Masuk Pelabuhan Rum, Retribusi Alat Berat, Retribusi Ijin Mendirikan Bangunan, Retribusi Ijin Trayek, Retribusi Ijin Usaha Perdagangan, Retribusi Surat Ijin Tempat Usaha, Retribusi Surat Tanda Daftar Perusahaan, Retribusi Izin Usaha Jasa Konstruksi, Retribusi Jasa Usaha Tempat Rekreasi. Retribusi dalam penelitian ini diukur dalam satuan rupiah (Rp).

\subsubsection{Lain-lain pendapatan pendapatan daerah yang sah (LPAD)}

Lain-lain pendapatan daerah yang sah yang merupakan penerimaan daerah yang tidak termasuk dalam jenis Pajak daerah, Retribusi daerah, Hasil pengelolaan kekayaan daerah yang dipisahkan. Lain-lain pendapatan daerah yang sah yang diperoleh Pemerintah Kota Tidore Kepulauan terdiri dari Pendapatan Lain-lain/Dok Lelang/Kelambatan, Penerimaan Jasa Giro, Pendapatan dari Pengembalian, Penerimaan Jasa Pihak Ketiga. Lain-lain pendapatan yang sah diukur dalam satuan rupiah (Rp).

\subsubsection{Teknik Analisis Data}

Menurut Nazir (1988:405), "Analisis data merupakan bagian yang amat penting dalam metode ilmiah karena dengan analisis, data tersebut dapat diberi arti dan makna yang berguna dalam memecahkan masalah penelitian". Selanjutnya penulis juga melakukan penafsiran dan interpretasi data. Menurut Nazir (1988:437) bahwa "Penafsiran dan interpretasi tidak lain adalah pencarian data yang lebih luas penemuan-penemuan. Secara umum penafsiran merupakan penjelasan terperinci mengenai arti yang sebenarnya dari materi yang dipaparkan".

Dalam menganalisis data, penulis menggunakan langkah-langkah sebagai berikut : 


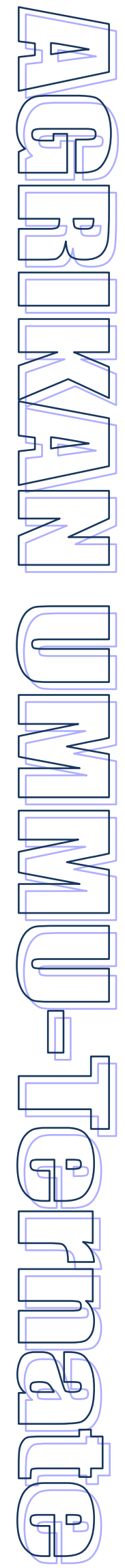

1. Analisis deskriptif ialah menyajkan menjelaskan, mendiskripsikan dan menganalisis data sebagaimana adanya pada pada saat penelitan ini dilakukan.

2. Analisis Kuantitatif analisis yang dilakukan secara sistimatis rasional dan metode yang dilakukan secara sistimatik,berdasarkan pola piker nduktif, deduktif, atau kombinasi keduanya tanpa perhitungan uji statitik.

3. Data dalam bentuk angka-angka yang disajikan dalam tabel sederhana dengan perhitungan presentase non uji statistik maupun non parametrik.

\section{HASIL DAN PEMBAHASAN}

\subsection{Hasil Penelitian}

\subsubsection{Gambaran Umum Kota Tidore Kepulauan}

Kota Tidore Kepulauan adalah satu daerah otonom yang dimekarkan dari Kabupaten Halmahera Tengah berdasarkan Undang-undang Nomor 1 Tahun 2003 tentang pemekaran wilayah yang diresmikan pada tanggal 31 Mei 2003. Secara geografis, letak wilayah Kota Tidore Kepulauan berada pada batas astronomis $0^{\circ}-20^{\circ}$ Lintang Utara dan pada posisi $127^{\circ}-127,45^{\circ}$ Bagian Timur. Kota Tidore Kepulauan memiliki total luas wilayah $1.550,37 \mathrm{Km}^{2}$ dengan daratan $9.116,36 \mathrm{Km}^{2}$ dan batas wilayah sebagai berikut :

Sebelah Utara Berbatasan dengan Kecamatan Pulau Ternate, Kota Ternate dan Kecamatan Jailolo Selatan Kabupaten Halmahera barat.Sebelah TimurBerbatasan dengan Kecamatan Wasile Selatan, Kabupaten Halmahera Timur dan Kecamatan Weda Kabupaten Halmahera Tengah. Sebelah Selatan.Berbatasan dengan Gane Barat Kabupaten Halmahera Selatan dan Kecamatan pulau Moti Kota Ternate.Sebelah Barat Berbatasan dengan Laut Maluku.Secara administratif, Kota Tidore Kepulauan terdiri dari 8 (delapan) kecamatan dan 72 desa/kelurahan dimana Kecamatan Oba Tengah dengan ibukota Akelamo adalah merupakan wilayah terluas $\left(424,00 \mathrm{Km}^{2}\right)$ dengan jumlah penduduk 7.659 jiwa dan kepadatan penduduk di kecamatan ini adalah 18. Sedangkan Kecamatan Tidore Timur dengan ibukota Tosa sebagai wilayah terkecil yakni seluas $34,00 \mathrm{Km}^{2}$ dengan jumlah penduduk 7.657 jiwa dengan tingkat kepadatan penduduk 225.

\subsubsection{Kondisi Perekonomian dan Keuangan Daerah Kota Tidore Kepulauan}

Secara umum kondisi perekonomian regional di Kota Tidore Kepulauan yang diukur berdasarkan perkembangan PDRB riel menunjukkan pertumbuhan positif rata-rata 5,97 $\%$ per tahun periode 2006-2010. Dari perspektif makroekonomi, tingkat laju pertumbuhan ekonomi yang demikian memberikan gambaran bahwa pembangunan ekonomi yang dilaksanakan pemerintah daerah setempat, telah mampu meningkatkan kinerja ekonomi di berbagai sektor serta menggerakan kondisinya ke arah pertumbuhan yang tinggi dan dinamis. Dilihat dari strukturnya secara parsial, tingkat laju pertumbuhan ekonomi tahunan di Kota Tidore Kepulauan memperlihatkan pola dan struktur yang semakin baik dengan kecenderungan pertumbuhan yang terus meningkat. Bahkan tingkat laju pertumbuhan ekonomi yang dihasilkan pemerintah daerah di kota ini relatif lebih tinggi $0,27 \%$ per tahun dibandingkan dengan pertumbuhan ekonomi Provinsi Maluku Utara, yang dalam periode yang sama hanya mencapai $6,14 \%$ per tahun.

Gambaran secara keseluruhan Pendapatan Asli Daerah tahun anggaran 2006-2010 dari komponen PAD yang telah diterima oleh kas daerah dapat dijelaskan masing-masing sebagai berikut:

\subsubsection{Pendapatan Pajak Daerah}

Dalam tiga tahun pertama yaitu tahun 2006-2008 realisasi penerimaan PAD tercapai target hal ini terlihat tahun $2006 \mathrm{Rp}$. 3.766.806.501 realisasi Rp. 5,237.252.048 $(139.04 \%)$, tercapainya target tahun ini karen keseluruhan komponen pajak daerah yaitu pajak hotel, pajak restoran, pajak hiburan, pajak reklame.penerangan jalan, dan pajak galian $\mathrm{C}$ mengalami kenaikan. Tahun 2007 target Rp.4.343. 487.151 realisasi Rp. 7.740.147.151 (178.20\%), juga tercapai realisai penerimaan, hal ini tidak terlepas dari sumbangan besar dari pajak hotel, pajak reklame, pajak galian $\mathrm{C}$ yang rata-rata melampaui target diatas ( 200\%). dibandingkan pajak restoran, pajak penerangan jalan dan pajak hiburan yang rata-rata dibawah (200\%). Selanjutnya tahun 2008 target Rp. 6.165.603.731 realisasi Rp. 7.329.361.321, $(118.87 \%)$ tercapai target pada tahun ini juga didominasi oleh pajak hotel, pajak reklame, pajak penerangan jalan targetnya diatas $(100 \%)$. Berikut untuk tahun 2009-2010 realisasi penerimaan PAD dalam dua tahun terakhir turun karena tiga item pajak yang rata-rata 
penerimaanya dibawah $(100 \%)$ antara laian pajak reklame, pajak penerangan jalan, serta pajak galian $\mathrm{C}$ tahun 2009. hal yang sama juga terjadi dalam tahun 2011, dibawah (100\%) antara lain pajak reklame, pajak penerangan jalan serta pajak galian $\mathrm{C}$ tahun 2009 . hal yang sama juga terjadi dalam tahun 2010.

Tabel 2. Rekapitulasi PAD Kota Tidore Kepulauan Periode 2006-2010

\begin{tabular}{cccccc}
\hline \multirow{2}{*}{ Tahun } & \multirow{2}{*}{ Target PAD } & Realisasi PAD & $\begin{array}{c}\text { Kinerja } \\
(\%)\end{array}$ & \multicolumn{2}{c}{ Pertumbuhan } \\
\cline { 6 - 7 } & & & $(\mathrm{Rp})$ & $\%$ \\
\hline 2006 & $3,766,806,501$ & $5,237,252,048$ & 139.04 & - & - \\
2008 & $4,343,487,151$ & $7,740,147,151$ & 178.20 & $2,502,895,103$ & 0.323365 \\
2009 & $6,165,603,731$ & $7,329,361,321$ & 118.87 & $-410,785,830$ & -0.05605 \\
2010 & $8,379,000,000$ & $7,242,978,515$ & 86.44 & $1,077,374,784$ & -0.01193 \\
\hline
\end{tabular}

Sumber : Dispenda Kota Tidere Kepulauan (2011)

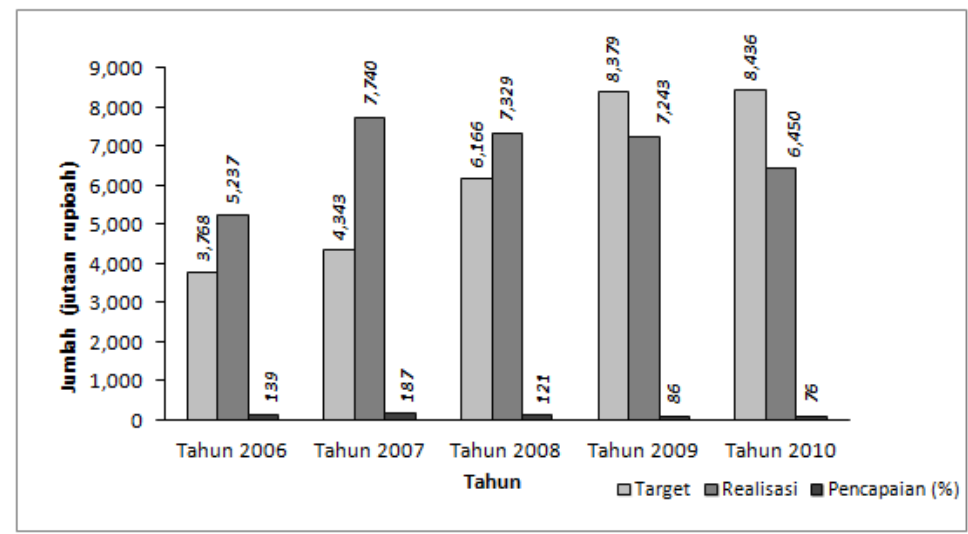

Gambar 1. Target dan Realisasi Pajak Daerah Kota Tikep

\subsubsection{Pendapatan Retribusi Daerah}

Jumlah realisasi pendapatan retribusi daerah Kota Tidore Kepulauan dari tahun 20062010 selalu tercapai target. Tahun 2006 target Rp. $\quad 1.384 .871 .900,-\quad$ realisanya $\mathrm{Rp}$. 1.894.227.000, (137\%) adapun tercapainya target retribusi dalam tahun ini yang terbesar didominasi oleh retribusi parkir kendaraan yang tercapai di atas $200 \%$ atau pertumbuhan sebesar (137\%) sedangkan retribusi yang lain rata-rata hanya mencapai 100\% lebih. Tahun 2007 target Rp.1.800.487.200 realisasi Rp.2.538.618.32 $(171 \%)$ pada tahun ini retribusi yang paling besar kontribusi adalah reribusi biaya cetak KTP sebesar (978\%). Sedangkan retribusi pelayanan kesehatan Puskesmas, ukuran pas kendaraan diatas air, juga tercapai target diatas 100\%; retribusi yang lain target tidak tercpai yaitu diawah (100\%), seperti, retribusi sewa alat berat, retribusi izin usaha,retribusi SITU, retribusi TDP serta reribusi jasa usaha tempat rekreasi.

Dalam tahun 2008 target retribusi Rp. 1.930.130.027, reaisasi penerimaan tercapai $\mathrm{Rp}$.
2.542.066.244,- (132\%). Hal ini ditunjang besarnya penerimaan retibusi biaya cetak akte sebesar (1.183\%). Selanjutnya pada tahun 2009 target Rp.2.614.000, realisasi tercapai Rp.2.764.802.474,- ( $106 \%$ ) kenaikan tersebut didukung oleh besarnya retribusi sertifikat kesempurnaan sebesar (889\%), dan beberapa jenis retribusi lain yang targetnya lebih dari $200 \%$, seperti retribusi parkir (322\%), retribusi izin usaha perdagangan (354\%), rertribusi cetak Akte $(216 \%)$ dan retribusi cetak KTP sebesar (225\%). Sedangkan pada akhir tahun 2010 target retribusi sebesar Rp. 2.777.000.000,- realisasi peneriman Rp. 2.799.335.520,- (101\%), tercapainya retribusi pada tahun ini, karena dominasi oleh retribusi Pelayanan Kesehatan RSUD yang mencapai (479\%) dibandingkan dengan retibusi daerah yang lain rata-rata mencapai sebesar (100\%-200\%). 
Tabel 3. Pendapatan Asli Daerah Kota Tidore Kepulauan Tahun 2010

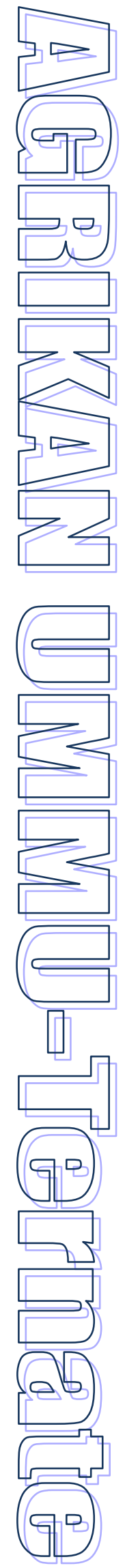

\begin{tabular}{lrrrr}
\hline \multicolumn{1}{c}{ Rekening } & \multicolumn{1}{c}{$\begin{array}{c}\text { Target } \\
\text { (Rp) }\end{array}$} & \multicolumn{1}{c}{$\begin{array}{c}\text { Realisasi } \\
\text { (Rp) }\end{array}$} & \multicolumn{1}{c}{$\begin{array}{c}\text { Kinerja } \\
(\mathbf{R p})\end{array}$} & \multicolumn{1}{c}{$\%$} \\
\hline -Pajak Daerah & $2,285,000,000$ & $2,035,584,973$ & $-249,415,027$ & $89.08 \%$ \\
- Retribusi Daerah. & $2,727,000,000$ & $2,799,335,250$ & $72,335,250$ & $102.65 \%$ \\
- Hasil pengelolaan & $140,000,000$ & $65,000,000$ & $-75,000,000$ & $46.43 \%$ \\
Kekayaan Daerah Yang Dipisahkan & & & \\
- Lain-lain Pendapatan Daerah yang & $2,899,000,000$ & $1,206,062,950$ & & $41.60 \%$ \\
sah & & & $1,692,937,050$ \\
- Lain-Lain Pendapatan Daerah & $385,000,000$ & $344,111,759$ & $-40,888,241$ & $89.38 \%$ \\
\hline Jumlah & $8,436,000,000$ & $6,450,094,932$ & & $73.83 \%$ \\
\hline Sumber: Dispenda Kota Tidore Kepulauan (2011) & & &
\end{tabular}

\subsubsection{Pendapatan Retribusi Daerah}

Jumlah realisasi pendapatan retribusi daerah Kota Tidore Kepulauan dari tahun 20062010 selalu tercapai target. Tahun 2006 target Rp. $\quad 1.384 .871 .900,-\quad$ realisanya $\mathrm{Rp}$. 1.894.227.000, (137\%) tercapainya target retribusi dalam tahun ini yang terbesar didominasi oleh retribusi parkir kendaraan yang tercapai di atas $200 \%$ atau pertumbuhan sebesar (137\%), sedangkan retribusi yang lain rata-rata hanya mencapai $100 \%$ lebih. Tahun 2007 target Rp.1.800.487.200 realisasi Rp.2.538.618.32 $(171 \%)$ pada tahun ini retribusi yang paling besar kontribusi adalah reribusi biaya cetak KTP sebesar $(978 \%)$. Sedangkan retribusi pelayanan kesehatan Puskesmas, ukuran pas kendaraan di atas air, juga tercapai target $100 \%$, retribusi yang lain target tidak tercpai yaitu diawah $(100 \%)$, seperti, retribusi sewa alat berat, retribusi izin usaha, retribusi SITU, retribusi TDP serta reribusi jasa usaha tempat rekreasi.

Tahun 2008 target retribusi Rp. 1.930.130.027, realisasi penerimaan tercapai Rp. 2.542.066.244,- (132\%). Hal ini ditunjang dengan besaranya penerimaan retibusi biaya cetak akte sebesar (1.183\%). Selanjutnya tahun 2009 target Rp. 2.614.000,- realisasi tercapai Rp. 2.764.802.474,- (106\%) kenaikan tersebut didukung oleh besarnya retribusi sertifikat kesempurnaan sebesar (889\%), dan beberapa jenis retribusi lain yang targetnya lebih dari $200 \%$, seperti retribusi parkir (322\%), retribusi izin usaha perdagangan (354\%), rertribusi cetak Akte $(216 \%)$ dan retribusi ceak KTP sebesar (225\%). Sedangkan tahun 2010 target retribusinya sebesar Rp. 2.777.000.000,- realisasi peneriman Rp. 2.799.335.520,- (101\%), tercapainya retribusi ini, karena dominasi oleh retribusi pelayanan kesehatan yang mencapai (479\%) dibandingkan dengan retibusi daerahnya.

\subsubsection{Hasil Pengelolaan Kekayaan Daerah Yang Dipisahkan}

Berdasarkan data bahwa penerimaan Hasil Pengelolaan Kekayaan Daerah yang Dipisahkan dari tahun 2006-2008 tidak terdapat tambahan penerimaan dari sektor ini, karena selama tiga tahun pertama tidak ada sumber penerimaan dikekola untuk meningkatkan PAD. Selanjutnya dua tahun terakhir dari 2009-2010 ada target dan realisasi namun hasilnya tidak seperti yang direncanakan.

\subsubsection{Lain-Lain Pendapatan Daerah Yang Sah}

Berkaitan dengan sumber Penerimaan Pendapatan lain-lain yang sah Kota Tidore Kepulauan pada tahun 2006 target Rp. 1.543.418,505, realisasi Rp.1.343.499.95, (157\%) tidak tercapainya target pada tahun ini karena sumber yang diperoleh untuk memberikan kontribusi Pendapatan Asli Daerah yaitu penerimaan Jasa giro dan pemakaian Gedung SKB, sedangkan sebagian lain-lain pedapatan daerah yang sah tidak ada sumbangsi tehadap PAD,. Berikut tahun 2007 targetnya Rp.1.434.499.95, realisasi Rp.3064.516.863, atau $(189 \%)$ tercapai target ini, didominasi oleh dua sumber utama: jasa giro dan sewa gedung SKB. Kemudian tahun 2008 realiasi tercapai Rp. 3.110.000.000,yang ditargetkan sebesar Rp.2.586.919.811, pertumbuhan $(121 \%)$, tercapai target dalam tahun ini hanya ditunjang satu sumber penerimaan yaitu penerimaan jasa giro sebesar (113\%). Sedangkan dua tahun terakhir yaitu 2009-2010 target tidak tercapai masing-masing tahun 2009 sebesar $(52 \%)$ untuk tahun 2010 juga mengalami penurunan sebesar (12\%). Target dan realisasi Lain-lain pendapatan daerah yang sah.Kota Tidore Kepulauan tahun 2006-2010. 
Deskripsi perkembangan ekonomi Kota Tidore Kepulauan periode 2006-2010 yang ditandai pertumbuhan PDRB riel yang positif sebesar 5,96\% per tahun sesungguhnya didorong oleh berbagai faktor yang dapat ditelaah dari aspek permintaan (demand) maupun penawaran (supply). Dari aspek penawaran, hingga tahun
2010 kondisi penawaran agregat (aggregate supply) masyarakat di kota ini cenderung membaik.

Pada tahun anggaran 2010 pendapatan daerah dianggarkan sebesar Rp. 8.436.000.000,dan terealisasi sebesar $\mathrm{Rp}$ 6.450.318.7156,-atau $76 \%$ dari target yang ditetapkan.

Tabel 4. Dana Bagi Hasil Pajak

\begin{tabular}{|c|c|c|c|c|}
\hline Uraian & $\begin{array}{c}\text { Target } \\
\text { Rp }\end{array}$ & $\begin{array}{c}\text { Realisasi } \\
\text { Rp }\end{array}$ & Pertumbuhan & $\%$ \\
\hline $\begin{array}{l}\text { Bagi Hasil Pajak PBB Migas } \\
\text { Bagi Hasil Perkotaan } \\
\text { Bagi Hasil intensif } \\
\text { Bagi Hasil PPH 21/25 } \\
\text { Bagi Hasil PBB Pusat } \\
\text { Bagi Hasi PBB Pedesaan } \\
\text { Bagi Hasil PBB }\end{array}$ & $\begin{array}{r}16.747 .641 .490,- \\
400.000 .000,- \\
200.000 .000,- \\
862.526 .133,- \\
2.605 .215 .723,- \\
-\end{array}$ & $\begin{array}{r}13.204 .626 .318,- \\
291.693 .737,- \\
2.423 .424 .069,- \\
2.646 .800 .894,-\end{array}$ & $\begin{array}{r}\text { 3.543.015.172,- } \\
108.306 .263,- \\
200.000 .000,- \\
(1.560 .897 .936,-) \\
(41.585 .171)\end{array}$ & $\begin{array}{r}78.84 \% \\
72.92 \% \\
280.97 \% \\
101.60 \% \\
\end{array}$ \\
\hline Jumlah & 22.615.383.346,- & 19.696.940.232 & 4.048.383.328 & $87.10 \%$ \\
\hline
\end{tabular}

Tabel 5. Dana Bagi Hasil Bukan Pajak / Sumber Daya Air

\begin{tabular}{lcccc}
\hline \multicolumn{1}{c}{ Uraian } & $\begin{array}{c}\text { Target } \\
\text { Rp }\end{array}$ & $\begin{array}{c}\text { Realisai } \\
\text { Rp }\end{array}$ & Pertumbuhan & \multicolumn{1}{c}{$\%$} \\
\hline Bagi Hasil dari luran HakPSDH & 1.470 .426 .874 & $598.706 .175,-$ & $81.720 .699,-$ & $40.72 \%$ \\
Bagi Dana Hasil Reboisasi & 1.088 .343 .593$. & $595.833 .875,-$ & - & $54.75 \%$ \\
Bagi Hasil Pertambangan Umum & 3.380 .295 .026 & $3.80 .295 .026,--$ & $492.509 .718,-$ & $100 \%$ \\
Bagi Hasil Perikanan dan PHP & 96.573 .477 & $171.312 .380,-$ & $(74.738 .903)$ & $177.35 \%$ \\
\hline \multicolumn{1}{c}{ Jumlah } & $\mathbf{6 . 0 3 5 . 6 3 8 . 9 7 0}$ & $\mathbf{4 . 7 4 6 . 1 4 7 . 3 3 0}$ & $\mathbf{1 . 2 8 9 . 4 9 1 . 6 4 0}$ & $\mathbf{7 8 . 6 4 \%}$ \\
\hline Sumber : Bagian Keuangan Kantor DIPENDA Kota Tidore Kepulauan & & &
\end{tabular}

Tabel 6. Dana Bagi Hasil Pemerintah Provinsi

\begin{tabular}{|c|c|c|c|c|}
\hline Uraian & $\begin{array}{c}\text { Target } \\
\text { (Rp) }\end{array}$ & $\begin{array}{l}\text { Realisasi } \\
\text { (Rp) }\end{array}$ & Pertumbuhan & $\%$ \\
\hline Bagi Hasil $\mathrm{P}$ & 500.000 .000 & 391.633.437, & 108.366 .563 & 78.33 \\
\hline Bagi Hasil BBN-KB & 500.000 .000 & 314.307.906. & 185.692 .094 & $62.86 \%$ \\
\hline Bagi Hasil PBB-KB & 1.194.000.000, & 1.473.122.178, & (279.122.178) & $123.38 \%$ \\
\hline
\end{tabular}

\begin{tabular}{|c|c|c|c|c|}
\hline Jumlah & $2.194 .000 .000,-$ & 2.209.814.861. & 14.936.487, & $100,72 \%$ \\
\hline
\end{tabular}

\subsection{Pembahasan}

Pengelolaan keuangan daerah sangat besar pengaruhnya terhadap nasib suatu daerah karena daerah dapat menjadi daerah yang kuat dan berkuasa serta mampu mengembangkan kebesarannya atau menjadi tidak berdaya tergantung pada cara mengelola keuangannya. Pengelolaan daerah yang dilakukan secara ekonomis, efisien, dan efektif atau memenuhi value for money serta partisipasi, transparansi, akuntabilitas dan keadilan akan mendorong pertumbuhan ekonomi yang selanjutnya mengurangi jumlah pengangguran serta menurunkan tingkat kemiskinan. Untuk pengelolaan daerah tidak hanya dibutuhkan sumber daya manusia, tetapi juga sumber daya ekonomi berupa keuangan yang dituangkan dalam suatu anggaran pemerintah daerah.

Hasil penelitian ini menunjukkan bahwa kondisi keuangan daerah Kota Tidore Kepulauan ditinjau dari komponen PAD yakni penerimaan pajak daerah, retribusi daerah, dan lain-lain pendapatan daerah yang sah sudah cukup baik. Namun secara umum, pertumbuhan PAD Kota Tidore Kepulauan selama periode 2006-2010, terlihat bahwa selama dua tahun terakhir kinerja pemerintah daerah dalam menggenjot PAD belum optimal. Hal ini dibuktikan dengan tidak 


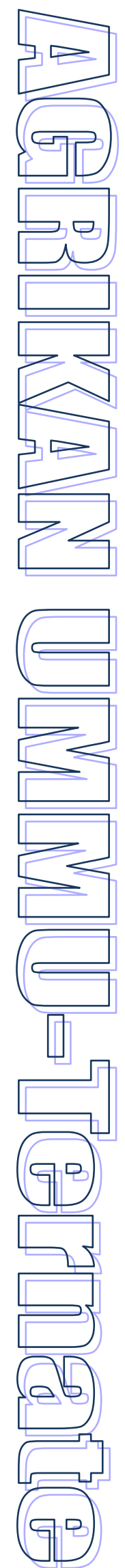

tercapainya realisasi PAD sebagaimana yang direncanakan pada Tahun 2009 dan 2010. Pendapatan yang diperoleh pada tahun 2010 tersebut didominasi oleh retribusi daerah yang melebihi target yang anggarkan. Sedangkan komponen PAD lainnya tidak memenuhi sebagaimana yang dianggarkan. Hasil penelitian ini menunjukkan bahwa rata-rata peningkatan konstribusi PAD Kota Tidore Kepulauan dari sektor pajak daerah sangat berfluktuasi bahkan pada tahun 2008 mengalami penurunan jika dibandingkan dengan tahun 2007 serta penurunan pada tahun 2010. Rencana penerimaan dari komponen retribusi daerah selalu terpenuhi dan meningkat setiap tahunnya, namun yang memberikan konstribusi terbesar terhadap penerimaan PAD Kota Tidore Kepulauan adalah Pajak daerah. Peranan pajak daerah dan retribusi daerah sebagai komponen PAD dalam menunjang total pendapatan daerah lebih besar jika dibandingkan dengan lain-lain pendapatan daerah yang sah.

Hasil penelitian ini sejalan dengan hasil penelitian Halim (2001) yang menunjukkan bahwa PAD masih berperan terhadap total penerimaan daerah, dimana retribusi merupakan komponen utama PAD yang lebih berpengaruh secara signifikan jika dibandingkan dengan pajak, sedangkan proporsi pajak daerah relative tidak berpengaruh terhadap Pendapatan Asli Daerah. Namun demikian dari data terlihat bahwa komposisi anggaran pendapatan daerah Kota Tidore Kepulauan masih didominasi oleh pendapatan yang bersumber dari dana perimbangan dengan kecenderungan yang meningkat. Dengan kata lain bahwa struktur pendapatan daerah di Kota Tidore Kepulauan yang terbentuk rata-rata 95,03\% bersumber dari dana perimbangan terhadap total pendapatan daerah, itu berarti derajat desentralisasi dan otonomi fiskal daerah di kota ini masih relatif rendah. Sehingga dapat dikatakan bahwa dalam periode 2006-2010 kebutuhan dana untuk pembiayaan berbagai aktivitas rutin pemerintahan dan pembangunan daerah masih memiliki ketergantungan yang tinggi terhadap keuangan pemerintah pusat. Hal ini mempertegas pendapat Yuliati (2001), bahwa untuk mencapai kemandirian daerah, pemerintah daerah seharusnya juga mengandalkan dana bagi hasil disamping PAD, karena terbukti lebih cepat mencapainya jika dibandingkan dengan hanya mengandalkan PAD semata.

Anggaran pendapatan daerah dalam APBD Kota Tidore Kepulauan periode 2006-2010 yang memperlihatkan bahwa, pendapatan daerah di kota ini masih mengandalkan penerimaan dari sumber dana perimbangan. Dan secara kumulatif dalam periode tersebut, Pendapatan Asli Daerah (PAD) baru memberikan kontribusi rata-rata sebesar Rp 5,700,533,805 atau 2,46 \% per tahun anggaran terhadap pendapatan daerah total.

\subsubsection{Optimalisasi Pajak Daerah}

Pajak Daerah merupakan iuran wajib yang dilakukan oleh orang pribadi atau badan kepada daerah tanpa imbalan langsung yang seimbang, yang dapat dipaksakan berdasarkan peraturan perundang-undangan yang berlaku, digunakan untuk membiayai penyelenggaraan pemerintahan daerah dan pembangunan daerah (UU Nomor 34 Tahun 2000, Pasal 1 ayat 6). Masalah kesenjangan fiskal dibalik tuntutan peningkatan kemandirian dalam rangka otonomi daerah Kota Tidore Kepulauan dan realitas rendahnya PAD lebih banyak disebabkan pada unsur perpajakan.

Lebih jauh mengenai perpajakan dan permasalahannya adalah karena kemampuan menghimpun dana kurang mengoptimalkan pengelolaan resources endowment, tuntutan pembangunan, dan tingkat urbanisasi. Masalah lainnya adalah terlalu banyaknya jenis pajak daerah dan sering tumpang tindih satu dengan yang lainnya. Tidak ada perbedaan yang jelas antara pajak dengan pungutan lainnya, dan masalah efesiensi penerimaan pajak.

Upaya optimalisasi PAD ternyata tidak didapat secara mudah, kebocoran pajak menjadi masalah utamanya. Itu terjadi akibat lemahnya kualitas aparat pemungut pajak, rendahnya kualitas hukum, dan pembiaran penyimpangan pajak oleh masyarakat. Pemerintah Kota Tidore Kepulauan sudah seharusnya menyusun rencana pencapaian target PAD hingga empat tahun ke depan. Proyeksi besaran PAD jangka panjang itu dimungkinkan untuk direvisi menjadi lebih tinggi jika kewenangan pengelolaan pajak bumi dan bangunan (PBB), bea perolehan hak atas tanah dan bangunan (BPHTB), dan pajak air tanah dialihkan dari pemerintah pusat kepada pemerintah kabupaten/kota. Itu jelas bukan tidak mungkin. Pasalnya, UU Nomor 28 Tahun 2009 tentang Pajak Daerah dan Retribusi Daerah mengamanatkan pengalihan BPHTB dan pajak air tanah menjadi pajak Kabupaten/Kota mulai 1 Januari 2011. Soal PBB, penyerahan paling lama awal 2014. Namun berbagai program besar itu harus diimbangi pembenahan sistem perpajakan termasuk SDM. Dari hasil pengamatan diketahui bahwa pegawai pajak yang ditugaskan di Kota Tidore masih sangat terbatas. 


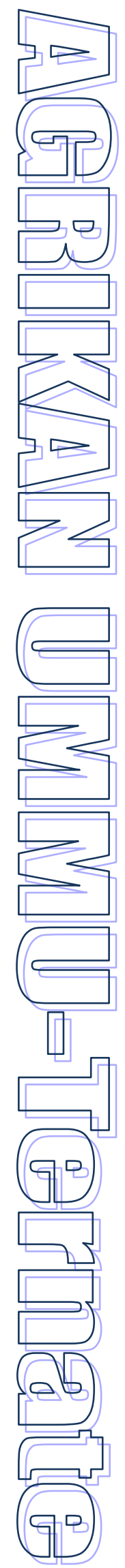

Dalam pelaksanaan kewenangan ini, Pemerintah Kota Tidore Kepulauan memerlukan beberapa dukungan, diantaranya adalah: 1). Dukungan dari Peraturan Daerah. Peraturan Daerah selain sebagai pola bertindak juga merupakan mekanisme kontrol bagi Pemerintahan Daerah serta sebagai pengakuan masyarakat kepada pemerintahannya, karena Peraturan Daerah dalam ketetapannya melibatkan DPRD sebagai wakil masyarakat daerah; 2). Kerja sama dengan Pemerintah Daerah lain. Tidak menutup kemungkinan apabila upaya kerja sama tersebut dilakukan akan dapat memberikan nilai tambah tidak saja satu daerah dalam wilayah Negara, tetapi sebagian wilayah yang memiliki lingkungan internal dan eksternal yang sama; 3). Adanya partisipasi dari masyarakat. Kaho (1991) menyatakan bahwa partisipasi masyarakat merupakan faktor penentu keberhasilan Penyelenggaraan Otonomi Daerah; 4). Sumber daya aparatur yang memadai, karena merupakan potensi yang penting dalam melaksanakan pemerintahan dan pembangunan di masa depan, apalagi dalam rangka otonomi daerah beban tugas pemerintahan semakin komplek dan berat. Ada beberapa kendala yang harus dapat ditanggulangi oleh Pemerintah Daerah dalam upaya untuk meningkatkan Pendapatan Asli Daerah. Adapun kendalakendala yang dihadapi dalam pelaksanaan kewenangan adalah: (1). Kendala Internal, diantaranya adalah: a). Ketidaksamaan pola pikir sumber daya aparatur di daerah dalam memahami dan mencermati visi dan misi daerah terutama pegawai yang berasal dari instansi vertikal dan sektoral; b). Adanya tumpang tindih dalam pembagian tugas pokok dan fungsi kelembagaan; c). Kurangnya peraturan daerah dari sisi jumlah dalam mengakomodasi kewenangan di Kota Tidore Kepulauan; (2). Kendala Eksternal, diantaranya adalah: kendala secara tidak langsung dari pemerintah pusat.

Kendala-kendala tersebut menurut Widodo (2002) terkait dengan otonomi setengah hati, karena kewenangan pemerintah yang masih mengatur dan mengendalikan pemerintahan di daerah. Kebijakan Pemerintah yang menjadikan kendala pelaksanaan kewenangan daerah adalah keluarnya Keputusan Presiden Republik Indonesia yang intinya telah menarik kembali kewenangan Pemerintah Daerah di Bidang Pertanahan yang merupakan kewenangan wajib bagi daerah. Selain itu pada tahun pertama berlakunya Undang-Undang Nomor 22 dan Nomor 25 Tahun 1999, kondisi perekonomian daerah sangat tidak menguntungkan karena imbas dari krisis ekonomi dan moneter secara nasional. Permasalahan yang krusial ini akan mempengaruhi kebijakan-kebijakan yang dapat diambil Pemerintah Daerah Kota Tidore Kepulauan dalam upaya optimalisasi peningkatan Pendapatan Asli Daerah terutama dalam mengimplementasikan pengelolaan kewenangankewenangan yang didesentralisasikan kepada daerah.

Hasil penelitian ini mendukung hasil penelitian Kustiawan (2002) yang menyatakan bahwa untuk mengoptimalkan pendapatan asli daerah sebagai sumber pendanaan bagi APBD adalah dengan meningkatkan jumlah pendapatan yang berasal dari pajak daerah. Akan tetapi hendaknya diperhatikan apakah peningkatan pendapatan tersebut tidak memunculkan masalah baru akibat reaksi masyarakat yang tentunya tidak akan menyetujui adanya kenaikan tersebut.

Secara empiris penelitian ini juga mengkonfirmasi hasil penelitian Ardiyana (2004) bahwa upaya pemerintah daerah mengoptimalisasikan Pendapatan Asli Daerahnya dapat menggunakan 2 (dua) cara yaitu Intensifikasi (dengan cara meningkatkan pendapatan asli daerah yang sudah ada, seperti Pajak daerah, dan Ekstensifikasi (yaitu upaya optimalisasi pendapatan asli daerah dengan cara mencari sumber-sumber pendapatan baru yang berasal dari pajak).

Beberapa kebijakan dalam usaha meningkatkan PAD yang dapat dilakukan oleh Pemerintah Kota Tidore Kepulauan diantaranya adalah :

a. Melakukan intensifikasi pemungutan pajak daerah dengan melibatkan SKPD secara efektif, melakukan penyelidikan pada objek/subjek pajak yang tidak membayar atau kurang membayar pajak daerah dengan yang telah ditetapkan dalam Surat Ketetapan Pajak dengan dilakukan kereja sama dengan lembaga penegak hukum yang terkait, dan melakukan uji petik atas beberapa pajak daerah untuk mengetahui potensi yang sebenarnya

b. Pengadaan sarana dan prasarana yang dapat menunjang upaya peningkatan pajak. Sarana dan prasarana merupakan salah satu faktor yang sangat menunjang suatu organisasi dalam melakukan tugasnya. Mengintensifkan pelaksanaan penyuluhan baik secara formal maupun informal terkait kesadaran masyarakat untuk membayar 


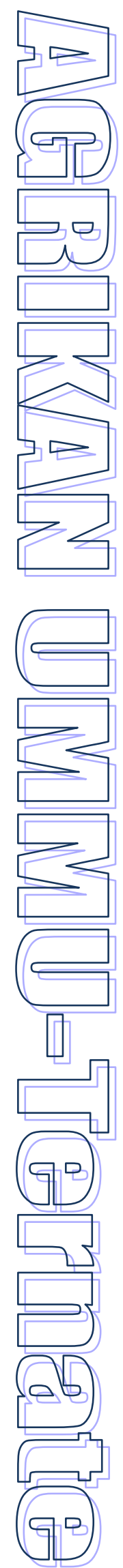

pajak. Kesadaran masyarakat untuk membayar pajak dan retribusi daerah harus selalu ditingkatkan. Karena jika kesadaran wajib pajak untuk mengembalikan SPT masih rendah, maka akan menghambat proses pemberian NPWPD, penetapannya maupun kaitannya dengan pembayaran pajak daerah. Kesadaran tersebut dapat ditingkatkan melalui penyuluhan. Penyuluhan ini dapat dilakukan secara langsung oleh Dinas Pendapatan Daerah (Dipenda) Kota Tidore Kepulauan dengan mengundang masyarakat ke tempat yang telah ditentukan kemudian diberikan informasi mengenai pajak dan retribusi daerah disertai dengan peringatan maupun saknsi apabila tidak melaksanakan kewajibannya. Ataupun dengan melakukan kerjasama dengan pemerintah kecamatan/kelurahan secara berkala), maupun dengan memanfaatkan tokoh masyarakat maupun tokoh agama melalui kegiatan kemasyarakatannya.

c. Sedangkan sistem penyuluhan secara tidak langsung dapat dilakukan dengan bentuk himbauan kepada msayarakat. Himbauan ini dapat dilakukan melalui iklan-iklan di media cetak, spanduk/reklame yang dipasang di jalan-jalan utama maupun slide film di media elektronik (radio dan televisi lokal) Penyuluhan ini hendaknya dapat menggugah kesadaran masyarakat untuk membayar pajak dan retribusi daerah serta menyampaikan informasi-informasi yang berkaitan dengan pajak.

d. Meningkatkan pelayanan terhadap masyarakat yang membayar pajak dan retribusi daerah dan lebih membuka diri terhadap masukan dari masyarakat serta melakukan pembinaan sikap mental, disiplin, motivasi kerja, dan pemahaman para pegawai terhadap tupoksi. Situasi politik yang tidak menentu dan reformasi yang melahirkan masyarakat yang semakin kritis menuntut Dinas Pendapatan Daerah (Dipenda) Kota Tidore Kepulauan untuk selalu berusaha meminimalisasi kelemahan yang dimilikinya, dengan meningkatkan sikap mental, disiplin, motivasi kerja para pegawainya, serta lebih bersifat transparan dan terbuka terhadap masukan dari masyarakat. Memberikan pelayanan kepada masyarakat dengan sebaik-baiknya merupakan tugas dari seluruh aparat pemerintah. Dan Dinas Pendapatan Daerah
(Dipenda) Kota Tidore Kepulauan sebagai ujung tombak pemungutan dan pengelolaan keuangan daerah juga dituntut untuk melakukan hal tersebut. Untuk itu Dinas Pendapatan Daerah (Dipenda) Kota Tidore Kepulauan terlebih dahulu harus bebas dari Korupsi, Kolusi, dan Nepotisme (KKN) baru setelah itu ia dapat meningkatkan kualitas pelayanannya. Untuk jangka pendek Dinas Pendapatan Daerah (Dipenda) Kota Tidore Kepulauan dapat menyediakan papan-papan petunjuk, seperti prosedur perijinan, tarif pajak, menindak secara tegas pegawai yang terbukti melakukan $\mathrm{KKN}$, bersikap ramah saat melayani masyarakat. Sedangkan secara jangka panjang Dinas Pendapatan Daerah (Dipenda) Kota Tidore Kepulauan dapat memperbaiki prosedur birokrasi menjadi pelayanan satu atap sehingga tidak berbelitbelit dan menyediakan kotak pos untuk menampung masukan dari masyarakat. Dengan lahirnya era reformasi pemerintah dituntut untuk lebih transparan dan lebih melibatkan partisipasi masyarakat secara aktif baik dalam proses perencanaan, pelaksanaan, maupun pengawasan proses pembangunan

Terkait dengan hasil penelitian Ismail (2002) bahwa rata-rata pajak daerah meningkatkan PAD setiap bulan dan terhadap APBD selalu meningkat rata-rata setiap tahun. Hasil penelitian ini menunjukkan bahwa rata-rata peningkatan konstribusi PAD Kota Tidore Kepulauan dari sektor pajak daerah sangat berfluktuasi bahkan pada tahun 2008 mengalami penurunan jika dibandingkan dengan tahun 2007 serta penurunan pada tahun 2010. Dengan demikian maka dapat disimpulkan bahwa hasil penelitian ini tidak sesuai dengan hasil penelitian Ismail (2002).

\subsubsection{Optimalisasi Retribusi Daerah}

Retribusi Daerah merupakan pungutan daerah sebagai pembayaran atas jasa atau pemberian izin tertentu yang khusus disediakan dan/atau diberikan oleh pemerintah daerah untuk kepentingan orang pribadi atau badan (UU Nomor 34 Tahun 2000, Pasal 1 ayat 26). Kebijakan yang diambil dalam rangka meningkatkan PAD dari sektor retribusi diantaranya adalah sebagai berikut:

a. Membebankan target penerimaan kepada SKPD .terhadap pungutan retribusi atas jenis retribusi yang timbul akibat pelaksanaan tugas pokok dari fungsi SKPD. 


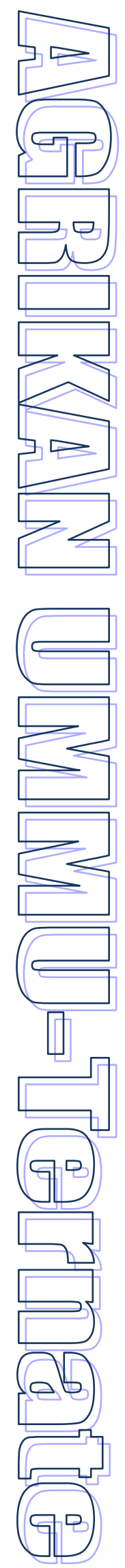

b. Melakukan intensifikasi pemungutan dengan cara :

(1). Menurunkan tim untuk membantu pungutan retribusi daerah.

(2). Meningkatkan pengawasan atas pengelolaan/pungutan retribusi

daerah yang dikelola oleh setiap SKPD

Hasil penelitian ini mendukung hasil penelitian Kustiawan (2002) yang menyatakan bahwa untuk mengoptimalkan pendapatan asli daerah sebagai sumber pendanaan bagi APBD adalah dengan meningkatkan jumlah pendapatan yang berasal dari retribusi daerah. Demikian halnya dengan pernyataan Kusumayoni (2004), bahwa kemampuan keuangan daerah yang diproyeksikan dalam pendapatan asli daerah, pajak daerah, dan retribusi daerah mempunyai pengaruh posotif dan signifikan, selanjutnya penelitian tersebut juga menunjukkan bahwa PDRB mempunyai pengaruh positif dan signifikan terhadap penerimaan pendapatan asli daerah, pajak daerah, dan retribusi daerah. Hal ini berlandaskan pada hasil penelitian yang menunjukkan bahwa rencana penerimaan dari komponen retribusi daerah selalu terpenuhi dan meningkat setiap tahunnya.

Secara empiris penelitian ini juga mengkonfirmasi hasil penelitian Ardiyana (2004) bahwa upaya pemerintah daerah mengoptimalisasikan Pendapatan Asli Daerahnya dapat menggunakan 2 (dua) cara yaitu Intensifikasi (dengan cara meningkatkan pendapatan asli daerah yang sudah ada yang bersumber dari pos retribusi daerah, dan Ekstensifikasi (yaitu upaya optimalisasi pendapatan asli daerah dengan cara mencari sumber-sumber pendapatan baru yang berasal dari retribusi).

Hasil penelitian Halim (2001) menyebutkan bahwa PAD masih berperan terhadap total penerimaan daerah, retribusi merupakan komponen utama PAD, berpengaruh secara signifikan dari pada pajak, sedangkan proporsi pajak daerah relative tidak berpengaruh terhadap PAD, hasil tersebut tidak sesuai dengan penelitian ini karena ternyata yang memberikan konstribusi terbesar terhadap PAD Kota Tidore Kepulauan adalah Pajak daerah.

\subsubsection{Optimalisasi Lain-Lain Pendapatan Asli Daerah Yang Sah}

Peraturan Menteri Dalam Negeri Nomor 13 Tahun 2006 tentang Pedoman Pengelolaan Keuangan Daerah, Pasal 25 ayat 4 menjelaskan bahwa: jenis lain-lain pendapatan asli daerah yang sah, disediakan untuk menganggarkan penerimaan daerah yang tidak termasuk dalam jenis pajak daerah, retribusi daerah, dan hasil pengelolaan kekayaan daerah yang dipisahkan. PAD memiliki peranan yang sangat penting dalam perekonomian daerah. Daerah yang memiliki tingkat pertumbuhan PAD yang positif mempunyai kemungkinan untuk memiliki pendapatan per kapita yang lebih baik. Dari data penelitian terungkap bahwa peranan pajak daerah dan retribusi daerah sebagai komponen PAD dalam menunjang total pendapatan daerah lebih besar jika dibandingkan dengan lain-lain pendapatan daerah yang sah. Untuk itu kiranya perlu usaha yang keras dari Pemerintah Kota Tidore dalam menggarap kedua sumber pendapatan asli daerah ini.

Upaya yang dilakukan oleh Pemerintah Kota Tidore Kepulauan dalam rangka meningkatkan PAD Kota Tidore Kepulauan selain dengan mengembangkan mekanisme revolving yang melekat pada lain-lain pendapatan dari PAD juga pada komponen PAD yang lain, termasuk Bagian Laba BUMD, yang apabila perlu dapat melakukan kerja sama dengan pihak lain di luar institusi Pemerintah Daerah atau Pemerintah Daerah lain. Upaya tersebut sejalan dengan "Model Intergovernmental Relations", dalam rangka otonomi daerah pungutan-pungutan baru dapat dilakukan dengan melakukan kerja sama dengan daerah lain agar pungutan yang telah ada dapat dioptimalkan. Dengan kewenangan yang dimiliki oleh Pemerintah Kota Tidore Kepulauan, pemerintah dapat memperluas dan mengatur pertumbuhan atau perkembangan daerahnya dari tradisional ke arah yang lebih metropolis.

Persoalan kemandirian pemerintah daerah Kota Tidore Kepulauan disebabkan oleh masalah makin membengkaknya biaya yang dibutuhkan pemerintah daerah untuk pelayanan public (fiscal need), sementara laju pertumbuhan penerimaan daerah (fiscal capacity) kurang dibanding dengan kebutuhan, sehingga terjadi kesenjangan fiskal di daerah. Oleh karena itu pemerintah daerah Kota Tidore Kepulauan perlu melakukan upaya peningkatan kapasitas fiskal daerah (fiscal capacity) untuk mengurangi ketergantungan terhadap pembiayaan dari pusat dalam rangka mengatasi kesenjangan fiskal dan sekaligus mendorong kemandirian.

Peningkatan kapasitas fiskal daerah Kota Tidore Kepulauan pada dasarnya adalah optimalisasi sumber-sumber penerimaan daerah yang salah satunya adalah peningkatan 
pendapatan asli daerah (PAD). Langkah penting yang harus dilakukan pemerintah daerah untuk meningkatkan penerimaan daerah adalah menghitung potensi pendapatan asli daerah yang riil dimiliki daerah Kota Tidore Kepulauan. Untuk itu diperlukan metode penghitungan potensi PAD yang sistematis dan rasional dimana PAD merupakan indikator bagi pengukuran tingkat kemampuan keuangan daerah dan tingkat kemandirian daerah.

Pada akhirnya keberhasilan otonomi daerah tidak hanya ditentukan oleh besarnya PAD atau keuangan yang dimiliki oleh daerah tetapi ada beberapa faktor lain yang dapat mempengaruhi keberhasilannya. Misalnya faktor kualitas sumber daya manusia, sarana dan prasarana, faktor sumber endowment, pengelolaan atau manajemen pemerintahan daerah dan sistem informasi yang tersedia. Pendapatan asli daerah (PAD) hanyalah merupakan salah satu faktor yang esensial dan mempengaruhi kelancaran penyelenggaraan otonomi daerah, terutama dalam pelaksanaan penitikberatan otonomi daerah pada kabupaten/kota. Selain itu tinggi-rendahnya PAD merupakan salah satu ukuran kredibilitas kemandirian kabupaten/kota dalam menyelenggarakan urusan rumah tangganya sendiri. Untuk itu diperlukan adanya langkahlangkah optimalisasi sebagai upaya meningkatkan pendapatan asli daerah sendiri tersebut agar kontribusinya terhadap Anggaran Pendapatan dan Belanja Daerah (APBD) terus dapat ditingkatkan.

Suatu daerah dikatakan otonom, apabila PAD yang disumbangkan sekitar 20\% (Devas, 1989). Kondisi yang terjadi di Kota Tidore Kepulauan, Pendapatan Asli Daerah hanya memberikan kontribusi kepada APBD selama enam tahun terakhir rata-rata kurang dari $10 \%$ dan justru mengalami penurunan mencapai $8.02 \%$ pada tahun 2001(setelah muncul mekanisme DAU). Kondisi ini belum ideal bila diisyaratkan dengan pendapat Devas di atas, pertumbuhan PAD paling tidak sesuai dengan pertumbuhan APBD dengan demikian apabila DAU berkurang dapat digantikan dengan PAD yang ada dengan besaran yang lebih besar pula.

Kewenangan yang dilimpahkan dari 11 kewenangan wajib dalam Undang-Undang Nomor 22 Tahun 1999 pasal 9 (2), pada dasarnya dapat dikembangkan tergantung kondisi dan kemampuan daerah dalam mengelola kewenangan tersebut. Pelimpahan kewenangan tersebut substansinya adalah agar pemerintah daerah dapat dan lebih intensif dalam menyediakan pelayanan kepada masyarakatnya. Selanjutnya dalam pasal 13 Undang-Undang yang sama dinyatakan bahwa pemerintah dapat menugaskan kepada daerah tugas-tugas tertentu dalam rangka tugas pembantuan disertai pembiayaan, sarana dan prasarana serta sumber daya manusia dengan kewajiban melaporkan pelaksanaannya dan mempertanggungjawabkannya kepada pemerintah. Jadi disamping ke-11 kewenangan wajib tersebut Pemerintah Pusat dapat melimpahkan kewenangan sesuai azas dekosentrasi yaitu penugasan yang pelaksanaannya oleh Pemerintah Daerah secara penuh serta melaporkan kepada Pemerintah Pusat, lebih lanjut diatur oleh Undang-Undang.

Dari kewenangan Daerah yang ada di Kota Tidore Kepulauan, belum semua kewenangan tergarap atau belum menunjukkan dampak yang berpengaruh pada peningkatan penerimaan Pemerintah Daerah Kota Tidore Kepulauan. Dari beberapa informasi yang diperoleh dapat diketahui bahwa ada sebagian kewenangan yang mampu memberikan penerimaan kepada Pemerintah Daerah yang belum dikelola karena kendala operasional dan Peraturan Pendukung termasuk Peraturan Daerah yang dapat dijadikan pijakan bagi instansi dan Dinas di Kota Tidore Kepulauan guna melakukan pungutan. Sudah seharusnya Peraturan Daerah ditetapkan guna mendukung upaya-upaya dalam rangka meningkatkan Penerimaan Daerah, karena Peraturan Daerah tersebut dijadikan landasan bertindak.

Dalam rangka pemungutan dan penggalian potensi di Kota Tidore Kepulauan lebih ditekankan pada efisiensi dalam pemungutan, salah satu diantaranya dengan perubahan tata laksana organisasi pemerintahan dengan membentuk dinas-dinas baru guna menampung pelimpahan wewenang dan tugas, yang selama ini dikelola oleh pusat. Kebijakan ini di samping untuk meningkatkan pelayanan kepada masyarakat dengan memperkecil biaya yang dikeluarkan juga dalam rangka intensifikasi penerimaan. Implementasi dari kebijakan itu salah satunya adalah ditetapkannya UndangUndang atau Peraturan dalam suatu wilayah yang disebut negara, dalam bentuk yang lebih kecil Peraturan Daerah merupakan hasil dari Kebijakan Pemerintah Daerah sehingga bentuk sikap Pemerintah Daerah dalam menerima pelimpahan kewenangan akan direalisasikan ke dalam Peraturan Daerah yang mampu mengikat warga 


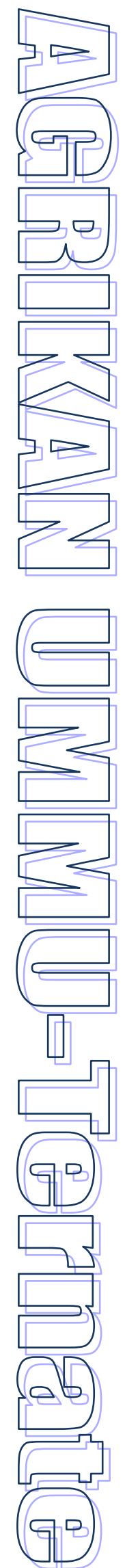

dan seluruh komponen di daerah.

Kekuatan Hukum Peraturan Daerah yang relative bersifat mengatur tersebut oleh Manan (2001) disebut dengan wewenang atributif. Kewenangan dalam Peraturan Daerah ditujukan dalam mengatur rumah tangga daerah yang dipegang Kepala Daerah (Walikota) bersamasama dengan Legislatif Daerah (DPRD). Dalam konsep otonomi keuangan daerah, sumbersumber kekuasaan atau kewenangan dampaknya bagi Pemerintah Daerah ditunjukkan oleh besarnya Pendapatan Asli Daerah, karena dengan PAD tersebut daerah berwenang dan berhak menggunakan dan/atau mengatur untuk kepentingan daerah sendiri, terbebas dari pengaruh dan campur tangan Pemerintah Pusat.

Peranan investasi dalam pembangunan ekonomi daerah adalah teramat penting terutama investasi swasta baik yang bersumber dari pihak swasta domestik (domestic investment) maupun swasta asing (foreign investment). Dewasa ini persaingan antardaerah di bidang investasi terjadi semakin kuat melalui promosi potensi sumber daya alam yang dimiliki serta penciptaan iklim yang kondusif untuk masuknya investasi. Berbagai upaya ini telah dilakukan Pemerintah Daerah Kota Tidore Kepulauan dan berhasil mengumpulkan investasi dalam jumlah dan perkembangan yang relatif besar. Akan tetapi, investasi yang ditanamkan para pengusaha di daerah ini baru sebatas investasi domestik lokal baik yang bersumber dari wilayah Kota Tidore Kepulauan sendiri maupun dari wilayah Provinsi Maluku Utara dengan nilai nominal yang masih terbatas.

Kekurangan investasi swasta dalam jumlah yang cukup besar untuk mendorong pembangunan ekonomi daerah terpaksa harus ditutupi dengan pengeluaran pemerintah dalam bentuk belanja modal. Selain komposisi sumber investasi yang masih bersifat lokal, perkembangan investasi swasta dan pemerintah di Kota Tidore Kepulauan periode 2006-2010 juga kondisinya cenderung bervariasi. Disisi lain, pertumbuhan pajak dan retribusi daerah Kota Tidore Kepulauan tidak optimal disebabkan pajak-pajak yang buoyant dan lucrative dikuasai oleh pemerintah pusat, pajak pendapatan, pajak eksport, atau oleh provinsi seperti pajak bea balik nama kendaraan bermotor (PBBNKB) dan pajak kendaraan bermotor (PKB). Pemerintah Kota Tidore Kepulauan hanya diberikan beberapa sumber pajak dan retribusi daerah yang potensial untuk dipungut, seperti pajak pembangunan I, pajak penerangan jalan, retribusi pasar dan terminal.

Untuk meningkatkan penerimaan pajak dan retribusi daerah diperlukan upaya peningkatan kapasitas produksi dan bisnis di daerah. Peraturan Daerah tentang Ijin Masuk Kota penting segera diterapkan secara efektif karena potensi ini juga akan meningkatkan Penerimaan Daerah. Guna meningkatkan PAD keberadaan terminal di pelabuhan sofifi penting untuk segera dimaksimalkan karena terminal ini efektif untuk mengakomodasi daerah lingkar kota yang bernuansa pedesaan dekat dengan kantong pertanian dan pusat pemerintahan provinsi, sehingga diharapkan mampu memobilisasi penduduknya ke arah kemajuan. Diharapkan dengan semakin meningkatnya fasilitas dan mutu pelayanan yang diberikan pemerintah daerah akan memberikan kelancaran bagi masyarakat untuk melaksanakan aktivitas sosial ekonominya sekaligus diharapkan meningkatkan kesadaran masyarakat dalam membayar pajak dan retribusi daerah.

Selain dari apa yang disebutkan diatas ada beberapa kebijakan fiskal yang diambil dalam rangka peningkatan penerimaan $\mathrm{PAD}$ yang sah antara lain.

a. Mengoptimalkan pemanfaatan dana daerah yang belum terpakai pada portofolia yang lebh menguntungkan, seperti peningkatan deposito pada Bank pemerintah atau Swasta.

b. Asset-asset daerah yang sudah tidak produktif dan menimbulkan biaya yang tinggi dalam operasional dan pemeliharaanya segera dilelang.

\section{PENUTUP}

\subsection{Kesimpulan}

Berdasarkan hasil penelitian maka dapat disimpulkan bahwa:

1. Kondisi keuangan daerah Kota Tidore Kepulauan ditinjau dari komponen PAD yakni penerimaan pajak daerah, retribusi daerah, dan lain-lain pendapatan daerah yang sah sudah cukup baik. Secara umum, pertumbuhan PAD Kota Tidore Kepulauan selama periode 2006-2010, terlihat bahwa selama dua tahun terakhir kinerja pemerintah daerah dalam menggenjot PAD belum optimal. Hal ini dibuktikan dengan tidak tercapainya realisasi PAD sebagaimana yang direncanakan pada Tahun 2009 dan 2010. Pendapatan yang diperoleh pada tahun 2010 tersebut didominasi oleh retribusi daerah yang melebihi target yang 


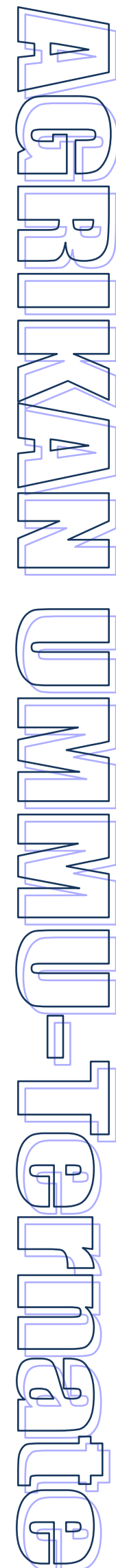

anggarkan (102,65\%). Sedangkan komponen PAD lainnya tidak memenuhi sebagaimana yang dianggarkan. Hasil penelitian ini menunjukkan bahwa rata-rata peningkatan konstribusi PAD Kota Tidore Kepulauan dari sektor pajak daerah sangat berfluktuasi bahkan pada tahun 2008 mengalami penurunan jika dibandingkan dengan tahun 2007 serta penurunan pada tahun 2010 . Rencana penerimaan dari komponen retribusi daerah selalu terpenuhi dan meningkat setiap tahunnya, namun yang memberikan konstribusi terbesar terhadap penerimaan PAD Kota Tidore Kepulauan adalah Pajak daerah. Peranan pajak daerah dan retribusi daerah sebagai komponen PAD dalam menunjang total pendapatan daerah lebih besar jika dibandingkan dengan lainlain pendapatan daerah yang sah.

2. Dengan berlakunya Undang-Undang Nomor 22 Tahun 1999 dan Undang-Undang Nomor 25 Tahun 1999, maka berbagai kewenangan telah dimiliki oleh Pemerintah Daerah pada umumnya dan Pemerintah Kota Tidore Kepulauan pada khususnya, namun dalam pelaksanaannya masih banyak kewenangan yang belum dilaksanakan secara optimal, baik secara intensifikasi maupun secara ekstensifikasi. Hal ini disebabkan karena Peraturan Daerahnya atau Surat Keputusan Walikota belum ada. Sebagai dampaknya Pendapatan Asli Daerah Kota Tidore Kepulauan masih kecil persentasenya dibandingkan dengan penerimaan pusat, walaupun sudah ada tambahan hasil yang berasal dari operasionalisasi kewenangan.

\subsection{Saran}

Upaya-upaya yang telah dilakukan oleh Pemerintah Daerah Kota Tidore Kepulauan perlu untuk dilanjutkan dan dievaluasi agar pelaksanaan kewenangan dapat dilakukan secara optimal. Apabila Pemerintah Daerah Kota Tidore Kepulauan dapat melaksanakan kewenangan dengan baik dan optimal, maka akan berdampak pada meningkatnya penerimaan pendapatan daerah. Adapun saran yang dapat disampaikan untuk meningkatkan upaya-upaya pelaksanaan kewenangan daerah dalam meningkatkan Pendapatan Asli Daerah adalah sebagai berikut:
1. Untuk mendorong kemandirian daerah dalam hubungan keuangan dengan pemerintah pusat, Pemerintah Daerah Kota Tidore Kepulauan perlu lebih meningkatkan realisasi penerimaan PAD di masa mendatang melalui : (1) koordinasi kebijakan yang efektif antara berbagai dinas yang menangani sektor perekonomian daerah, (2) perencanaan yang bersifat integratif dengan melibatkan semua instansi / dinas yang terkait, (3) perhitungan potensi ekonomi PAD secara cermat dan akurasi dalam penerjemahan potensi ke target, (4) pengawasan yang ketat terhadap kegiatan pengumpulan PAD. (5) Pihak legislatif perlu untuk bekerja keras dalam menetapkan dan mengevaluasi Peraturan Daerah yang sudah ada maupun yang akan ditetapkan.

2. Perlu adanya penerapan sistem penghargaan (reward) dan hukuman (punishment) terhadap aparatur atau instansi yang terlibat dalam program peningkatan Pendapatan Asli Daerah (PAD). Sistem penghargaan dan hukuman ini dilakukan untuk meningkatkan semangat kerja aparatur pemerintah daerah dan sekaligus menghambat aparatur yang berbuat tidak benar.

3. Dalam upaya peningkatan pendapatan daerah, pihak eksekutif perlu untuk menggunakan strategi dan inovasi yang dapat diterima dan meningkatkan kesadaran masyarakat dalam ikut serta membangun daerah melalui pembayaran pajak dan restribusi yang telah ada dasar peraturannya.

4. Bagi penelitian selanjutnya perlu menambah, mengurangi atau mengganti variabel-variabel tersebut dengan variabel-variabel lain yang dimungkinkan dan relevan dengan keuangan daerah khususnya yang berkaitan dengan Pendapatan Asli Daerah. Selain itu penelitian ini dapat dikembangkan pada obyek yang sama, waktu yang berbeda maupun pada obyek yang berbeda, pada waktu yang berbeda pula. Selain itu dapat pula dipakai sebagai acuan pada obyek yang sama waktu yang berbeda, obyek yang berbeda waktu yang berbeda dengan model analisis yang berbeda pula. 


\section{DAFTAR PUSTAKA}

Adi, Priyo Hari. 2005. Dampak Desentralisasi Fiskal Terhadap Pertumbuhan Ekonomi. Jurnal Kritis. Universitas Kristen Satya Wacana. Salatiga.

Ahmad, (2003). Pengaruh Beberpa Indikator Ekonomi Terhadap PAD Kota Pekanbaru Riau (Tesis tidak dipublikasikan )Program Pasca Sarjana UNPAD Bandung.

Ardianayah (2001), Pennerimaan pajak Daerah Terhadap PAD di Daerah Pemerintah Kota Blitar.

BAPPENAS. (2003). Peta Kemampuan Keuangan Provinsi Dalam Era Otonomi Daerah: Tinjauan atas Kinerja PAD, dan Upaya yang Dilakukan Daerah. Direktorat Pengembangan Otonomi Daerah.

Devas, Nick, 1989, Keuangan Pemerintah Daerah Di Indonesia, Terjemahan Masri Maris, UI-Press, Jakarta

Englini (2001)., Pentingnya Penyusunan Remncana PAD Jangka Menengah dan Menunjang Akuntansi Manajemen pada Dinas pendapatan Daerah Kota Padang bunga Rampai manajemen Keuangan Daerah Edisi Pertama UPP.SAMP.YKPN Yogyakarta 2001.

Eryani Analisis Penerimaan Pendapatan Asli Daerah (PAD) dalam kaitannya dengan Anggaran Pendapatan dan BelanjaDaerah (APBD)Propinsi Lampung (Tesis tiak dipublikasikan Program Pasca Sarjana MM UNILA

Ghozali, Imam. 2006. Statistik Multivariat SPSS. Penerbit Badan Penerbit Universitas Diponegoro. Semarang.

Halim, Abdul, (2004). Bunga Rampai Manajemen Keuangan Daerah, Yogyakarta: UPP YKPN.

Ismail (2001), Pendapatan Asli Daerah Dalam Otonomi Daerah, Fakultas Ekonomi Universitas Brawijana Tema Volume II. No. 1 Maret, 2001.

Kaho (2001), Prospek Otonomi Daerah di Negara Repoblik Indonesia Cetakan ke lima Jakarta, PT.Rajagrafindo Persada

Koswara (2001). Otonomi Daerah Untuk Demokrasi dan Kemandirian Rayat Yayasan Pariba Jakarta.

Kusumayoni (2004), Analisis Kemampuan Keuangan Daerah Dalam Membiayai Pengeluaran Daerah di Kabupaten Klinhgking .Tesis S2 PPs UNPAD Bandung (tidak dipublikasikan)

Manan, Bagir (2001), Menyongsong Fajar Otonomi Daerah, Cetakan I, Pustaka Pelajar Offset, Yogyakarta

Mardiasmo (2000) Perhitungan Pajak dan Retrinbusi Daerah di Kabupaten Magelang laporan akhir Kerja sama Pemda Kabupaten Magalang dengan PAU-SE.UGM (2002), Akuntansi Sektor Pablik. Andi Yogyakarta. (2002), Otonomi Daerah dan Manajemen Keuangan Daerah Andi Yogyakarta.

Munawir (2000), PerpajakanEdisi Kelima, Cetakan Keempat, Yogyakarta Liberty

Novita Firda ( 2005), Peranan Pendapatan Asli DaerahTerhadap Kemampuan Pembangunan Daerah Skripsi (Tidak dipublikasikan) UNRI.

Peraturan Pemerintah Nomor 84 Tahun 2001 Tentang Perubahan Atas PeraturanPemerintah Nomor 104 Tahun 2000nTentang Dana Perimbangan

Peraturan Pemerintah Dalam Negeri Nomor 26 Tahun 2006 Tentang Pedoman Penyusunan Anggaran Pendapatan dan Belanja Daerah 2007

Saragih (2003), Disentralisasi Fiskal dan Keuangan Daerah dalam Otonomi Ghalia Indonesia Jakarta

Sidik, Machfud, 2002. Format Hubungan Keuangan Pemerintah Pusat dan Daerah yang Mengacu Pada Pencapaian Tujuan Nasional, Seminar Nasional "Publik Sector Scorecard, Jakarta, 17-18 April 2002.

Simajuntak (2003), Hukum Pajak Nomensen - press Medan (2002), Fiscal Net dan Fiscal Capasity dalam rangka Optimalisasi PAD Departemen Keuangan.

Undang-Undang No. 34 Tahun 2000 Tentang Perubahan atas Undang Undang RI No. 18. Tahun 1997 Tentang Pajak Daerah dan Retribusi Daerah

Widodo, Joko (2002), Good Governance, Telaah dari Dimensi: Akuntabilitas dan Kontrol Birokrasipada Era Desentralisasi dan Otonomi Daerah, Insan Cendikia, Surabaya

Yani (2008), Hubungan Keuangan Antara Pemerintah Pusat dan Daerah di Indonesia Rajagrafindfo Persada Jakarta. 